\title{
IDENTITY OF PLACE, PLACES OF IDENTITIES \\ CHANGE OF PLACE NAMES \\ IN POST-APARTHEID SOUTH AFRICA
}

Sylvain GUYOT

\section{Cecil SEETHAL}

\section{Sylvain GUYOT}

University of Fort-Hare, Department of Geography and Environmental Studies \& University of Grenoble 2, Department of Social Geography

4, rue Etienne Marcel

38000 GRENOBLE

FRANCE

sylvainafrica@,free.fr

Cecil SEETHAL

University of Fort-Hare, Department of Geography and Environmental Studies

Private Bag X1314

ALICE 5700

SOUTH AFRICA

cseethal@ufh.ac.za

version 3 - 30/09/2006 - 7443 words - accepted for publication, South African Geographical Journal 1-2007

The paper has not been submitted elsewhere for publication.

S. GUYOT

Paper realised through the CORUS research programme (IRD, University of Grenoble $1 \& 2$ and University of Fort-Hare). Thanks to Sylvie Hessel for assisting with fieldwork, and to Dr. Frédéric Giraut, Dr. Benoit Antheaume and the anonymous referees for their comments on the paper. An earlier version of this paper was presented at the Society for South African Geography Conference at the University of the Western Cape, 7-9 ${ }^{\text {th }}$ September 2005. 


\title{
IDENTITY OF PLACE, PLACES OF IDENTITIES \\ CHANGE OF PLACE NAMES IN \\ POST-APARTHEID SOUTH AFRICA
}

\begin{abstract}
Various types of transformations of toponyms coexist today in South Africa at every scale: street, suburb, village, town, city, municipality, district, province and country. Place names contribute to forge the identity of particular places, at different scales. The combination between place and scale creates various sets of identities. The change of place names is a pertinent tool to analyse territorial restructuring in post-apartheid South Africa. It raises the question of multiculturalism in a 'multilingual coexistence context'. Thus, it emphasises the question of memory of a past that new names want to rectify or to clear. Change of place names is at the intersection of spatial strategies and representations of all individuals. It is an entry point to study the evolution of today's identities in South Africa. If toponyms reflect the identity of a place, their changes are indicative of the multiple identities contained in one place or territory.
\end{abstract}

\section{Introduction}

The process of renaming places is inextricably linked to political changes in different parts of the world. What are the motives behind such name changes in global contexts? This paper uses South Africa as a case study to develop some theoretical grounding based on post-independent African states.

If you are a white South African, chances are you've heard somebody you know complaining about all the place names being changed (e.g., "Polokwane" for "Pietersburg"). Some of those people might be under the impression that some government officials apparently had nothing better to do ... than sit around and make up strange new difficult to pronounce names for places. What many do not realise though, is that those "new" names are mostly not new at all, but are merely the names that black people have been using for those places for decades, and in some cases, centuries. ${ }^{1}$

This quotation illustrates a particular perception about the change of place names in South Africa at the beginning of the $21^{\text {st }}$ Century. It helps to understand how sensitive the subject is in a country where the place names are symbols of racial identity, and are contested along race and ethnicity. Place names, or toponyms, are directly related to the place of the people: place in which inhabitants are included, or from where they are excluded, as well as to "ideological and nation-building constructions" (Horsman, 2006:279). In general, individuals perceive spatial and mental places described by toponyms differently. Geographical analysis on change of place names is new in South 
Africa, and warrants research. This is particularly so because place naming is, from a geographic point of view, a territorialisation process that contributes to the identity of particular places, at different scales (Guillorel, 2003). This combination between place and scale creates various sets of identities. The change of place names therefore constitutes a critical tool to analyse territorial restructuring in post-apartheid South Africa within a new nation-building context.

Controversies around changes of place names need to be positioned within the context of divisions between nationalism and internationalism. These divisions remain unresolved in South Africa at the present time, though the balance appears to be tipping towards a more ethnically defined nationalism. The politics of name changes that incorporate the politics of street names and states cannot be separated from conflicts and tensions over political and cultural hegemony amongst different constituencies in South Africa. Thus, it raises the question of multiculturalism in a 'multilingual coexistence context' (Jenkins, 2004) and it emphasises the question of memory of a past that new names want to rectify or clear (Coombes, 2004). Changes of place names are at the intersection of spatial strategies and representations of all individuals (Guyot, Gebrati, Seethal, Giraut and Antheaume, 2005). It is an entry point to study the evolution of present identities in South Africa. If toponyms reflect the identity of a place, their changes are indicative of the multiple identities contained in one place or territory.

South African toponyms' specialists (e.g., Coetser, 2002; Jenkins, 2003; Raper, 1989) distinguish between geographical names (i.e., regions and natural features) and place names (i.e., houses, settlements, towns, municipalities and provinces). This paper focuses on place names. Various changes or creations of names of places, spaces or territories coexist today in South Africa at every scale: street, suburb, village, town, city, municipality, district, province and country. These include the debates that emanated from the Pan African Congress (PAC) (including groups originating as schisms from it, e.g., the Azanian People's Organization) and the Black Consciousness Movement, in the 1960s and 1970s respectively, to change the name, 'South Africa' to Azania. These 'Africanist' political organizations argued that the name 'South Africa' had colonial origins, and was symbolic of imperial and colonial (including internal colonial) domination of the indigenous and oppressed peoples of the land. For these political organizations, the name 'Azania' was symbolic of self-determination, national liberation, and a free and independent black republic. ${ }^{2}$ However, by the 1990s, there was little support either within the Constitutional Assembly or without for a change of name of the country. ${ }^{3}$ In this regard, South Africa was different from Namibia where the parties in opposition (including the Democratic Turnhalle Alliance) to the hegemonic South West African Peoples' Organization (SWAPO) successfully lobbied for the adoption of the name 'Namibia' instead of 'South West Africa'.

The decision level responsible for name making is different in function with respect to the scale of the place (see Table 1). Both national and local representatives have power on this matter. Also, the international marketing power of place names differs as a function of scale. This implies a gradation of the international stakes around changes or creations of place names. Country, province and city names are politically sensitive and symbolic issues because they guarantee, in part, the international recognition of place. Furthermore, the duration of acceptance of changes is variable: it depends on the people, their history and itineraries; the speed with which successor regimes seek to replace the symbolic culture of their predecessors; the distance a place is away from the centre of political power (Gill, 2005, cited in Horsman, 2006); and 
whether one is dealing with urban spaces or rural landscapes (Horsman, 2006). For example, with the exception of the Greeks, people everywhere speak about Istanbul and not about Constantinople ${ }^{4}$ or Byzance!

\section{Table 1}

Name changes in South Africa have been largely restricted to street naming, the correction of spelling errors of the names of cities and towns, ${ }^{5}$ rectifying incorrect (or 'corrupted') transcriptions of indigenous names during colonialism, and the introduction of names seeking to legitimise the new political regime. These changes have increased with the start of negotiations on new names for towns and cities, more especially with the demarcation of new municipalities in 2000.

In attempting to understand how the change of place names can be used as a tool to analyse territorial restructuring in South Africa, various methods and sources of evidence were used to collect the data. Following Flowerdew and Martin (2005), Hoggart, Lees and Davies (2002), and Limb and Dwyer (2001) qualitative methodologies were used during the principal research periods in November 2004 and September 2005 and included participation observation (e.g., field observations of places in the Eastern Cape and Gauteng), interviews and the analysis of documentary materials. The empirical work comprised thirty, one-on-one personal, semi-structured, open-ended, in-depth interviews - with the interviewees chosen on the basis of the snowball technique. In an attempt to maximize polyvocality, the interviewees included representatives from the place names' committees, national and local politicians, stakeholders within the Non-Governmental Organization (NGOs) sector, and residents. In addition, meetings were held with socio-linguists and academic specialists of place names in South Africa. ${ }^{6}$ The information obtained via interviews, observations and meetings were supplemented with a comparative literature review of French- and English-speaking texts emanating from socio-linguistics and cultural geography, and a study of key web sites, including the South African Geographical Names Committee web site (www.sagnc.org.za) for data sets relative to the post-2000 demarcated municipalities.

This paper comprises four parts. The first argues that place names are a political instrument used to link place and identity. The second provides the context of official name making in South Africa since the colonial era. The third elaborates on toponyms as creators of a new identity of place linked to new nation-building imperatives. The fourth illustrates briefly that places contain many different identities that either oppose name changes or create imaginative naming. ${ }^{7}$

\section{Toponym: Linking Place and Identity}

This paper adopts the conceptual framework of the (changing) political relations between place (name) and identity. Within this context, toponym constitutes one of the vectors in the definition of the identity of a place, with nation building using the change of place names as a politico-territorial tool. In addition, the change of toponym is illustrative of multi-identities sharing a given place, including grass-root toponym opposition and (re)creation.

Place is used as a noun to denote location - though principally with what is located there. Consequently, much has been written about the 'sense of place', in which 
people strongly identify with a particular geographical area or location (Bekker \& Prinsloo, 1999; Dixon \& Durrheim, 2000; Low \& Lawrence-Zuniga, 2003; Palmberg, 1999; Reid, 2004; Ryan, 2005). Place name therefore plays a major role in the creation of a positive or negative 'sense of place'. Names change because society changes. However, place names are often transformed to propose or bring about evolution in society. Thus Meiring writes:

What does society adopt when a name is accepted? What does the name represent? The very symbolic nature of a name, its whole historical, cultural, social, topographical and linguistic backing, has its bearing on the degree of acceptance of a particular change (1994:69).

In a society characterised by a multiplicity of diverse political and cultural values, changes in place names can be a unifying or dividing catalyst. In this regard, place names may be used as symbols to mobilise and develop a political and historical consciousness of common identity. African countries at the end of the colonial period illustrate this idea with the name 'Zimbabwe', for example, replacing 'Southern Rhodesia' (Bopda, 2001; Mamdani, 1996). The new name, 'Zimbabwe', symbolises the historical greatness of the Shona homeland with particular reference to the kingdom of Monomatapa and the archaeological site of 'Great Zimbabwe'. Elsewhere, other postcolonial societies also changed names: Saigon to Ho Chi Minh City; Batavia to Jakarta; Leopoldville to Kinshasa, Bombay to Mumbai. Similarly, Ranger $(1989,1996)$ provides important examples of place and street name changes in Namibia, while Horsman (2006) records that Pamiri toponyms correspond with the basic pattern seen in the case of urban toponyms in the former Soviet Union. In this regard he notes:

In both cases, each historical period produced the same types of names and for the same reasons. The toponyms reflected the political climate of the time: the pre-Tsarist period produced traditional, physical and mythical names; the Tsarist period, names after members of the Royal Family, and the empire's soldiers and explorers; the early Soviet period, names honouring contemporary Bolsheviks, ideals and institutions; the late Soviet period, dead Communists, anniversaries and the wider international socialist movement related names; and the post-Soviet period, a limited number of names seeking to legitimise the new regimes by locating them in a longer non-Russian/Soviet historical continuum (2006:288).

Thus, the name 'St Petersburg' replaced 'Leningrad' in Russia even though it is rooted in another imperialist past.

In South Africa, identities are constructed and are continually changing given the multitude of variables that shape it, including race, ethnicity, history, culture, religion and language. The question is: How does one define a common or national identity in a pluralistic society in which multiculturalism recognises differences that should be respected and affirmed. The problem with being segregated in terms of race and ethnic groups is that it contributes to essentially cultural exclusivity, and outsiders can never join. Thus de Jager notes: 
South Africa's constitution serves to protect, encourage and celebrate the pluralism of this nation. On the one hand plurality should be celebrated and encouraged, while at the same time a national identity should be built on a common political culture, which overarches multiculturalism (2005:4).

A move from nationalism to multiplicity, division and difference can be problematic in South Africa, as the reconstruction of society requires a common commitment and a sense of collective responsibility (Brown, 2001). Thus, when the slogan "one nation, many cultures" was introduced in South Africa, it was not universally adopted. These differences played themselves out in the changes of the names of places. In consequence, there were those who wished to cling to the old names, while the others who accepted multiculturalism advocated dual names, for example, KwaZulu-Natal, so that the old names would be preserved.

Place names in South Africa are contested essentially along race and ethnicity (and less so on multiculturalism) given that the names are spatial symbol of colonialism, racial appropriation, segregation and apartheid. This situation prevails in spite of the three core concepts of nation building, non-racialism and reconciliation that served to express the consensual alternative to apartheid and interracial antagonisms. Consequently, Moodley and Adam (2000) ask the question: Can nation building in South African succeed in the light of the global ethnic renaissance, particularly after the end of the Cold War? In this regard, Meiring notes:

It is not easy to decide whether a case of change of place name in an area would have legitimacy or whether it would be an even greater barrier to reconciliation. After all, the success of nation building is also based on the democratic ideal of making the public feel that they are shapers of society and history and not mere bystanders or victims of social change (1994:75).

Meiring further adds that when a place name is recognised by a community as a beneficial symbol and it receives official recognition, the result is an increase in the legitimacy of government authority. Nonetheless, the intrinsic qualities of place names make them tools of strong debate. No toponym is completely neutral in the shared memory of a society and its various networks because the very essence of names is their descriptive contents, and the things people and societies identify with when using the name. This explains why most of the toponyms created during the colonial and apartheid eras were rejected.

\section{Institutional Place Name Making in South Africa}

Before the creation in 1939 of the first regulatory body for place name making in South Africa, the white settlers named most places with an emphasis on English and Afrikaans names. Sometimes the colonisers tried to conserve or adapt indigenous names, but most of these names were 'transformalised' with many spelling errors, thus 'corrupting' the indigenous names. Coetser succinctly captures this process as follows:

For instance the Tone language: they have two tones and a change of tone brings about a change of meaning. And a change of meaning can change all 
contexts. It is important to have the names spelt correctly. The colonisers started writing it the way they would pronounce it and it was a total corruption, or if you want the linguistic term for it, a transformalisation of the original word. So we are looking into that. Should it be changed back to its original pronunciation, or should it be kept like it is now? We have the example of Gonubie, but the original pronunciation is $\mathrm{K}$ !onoobie. But the colonisers could not make the click sound, so they made it Gonubie ${ }^{8}$.

South African place names also include certain place names from Europe as well as those after colonial heroes (Pretoria after Pretorius, Durban after d'Urban). Natural elements (and animals) are also widely used. For example, one can speak about Springbok, name of a town in Northern Cape, symbol of the Union of South Africa blazon and name of the national rugby team since 1906. The springbok is the epitome of the wildlife and open spaces of the country and has been the sentimental focus on identity for most white South Africans in the 20th Century (Jenkins, 2004).

In 1939, the National Place Name Committee (NPNC) was created. It had consultative powers but no decisional ones. It was in charge of the names of towns, cities, suburbs, post-offices and stations. It comprised mainly academics that were aligned closely to the hegemonic political grouping. The challenge facing the NPNC started during the apartheid era, and centred on the representation of Afrikaans in comparison with English (Jenkins, 1990). Consequently, between 1977 and 1987, the NPNC registered a large proportion of the names of new place in Afrikaans. In keeping with the ethnic design of grand apartheid, many of the new names were also in the Bantu languages. (There are no known attempts to change the place names created in the former Bantustans). It was also the time for the adoption of bilingual names for cities and town (East London and Oos London; Richards Bay and Richardsbaai; Cape Town and Kaapstad), while only a few new symbolic places had a nationalist tone: Triomf and Verwoerdburg (after Verwoerd, prime minister of South Africa from 19581966) in the Johannesburg area. Simultaneously, the decision to change Roberts Heights in Pretoria to Voortrekkerhoogte generated much resentment amongst Englishspeaking South Africans. These changes were reminiscent of the anti-imperial rhetoric of leading Afrikaner nationalists in the 1930s, highlighted by Dunbar Moodie, among others. For example, Afrikaner nationalists/republicans would have regarded Durban (d'Urban) as a colonial name, but Pretoria (Pretorius) as an anti-colonial name! While careful not to homogenise all whites into one process of colonization, it is important to note that many English speakers resented the Afrikaner version of English place names during the period of Afrikaner nationalist dominance (e.g., Grahamstown to Grahamstad, while Bloemfontein was not rendered into English as 'Flower Fountain').

After the demise of apartheid in the early 1990s, the NPNC changed in accordance with the new democratic dispensation and incorporated black experts in the nine new official African languages. During the political transformation of the 1990s, the NPNC tried to erase deliberately racist names, like the ones including the word, 'kaffir'. Airport names have changed too (D.F. Malan to Cape Town International; Jan Smuts to Johannesburg International and more recently (in 2006) to O.R. Tambo International; Louis Botha to Durban International). The name of an airport is crucial at the international level. For South African airports, one can speak about an early neutralisation process, as the name of the city followed by the adjective, 'international', did not imply any substantive transformation. 
A new name committee, the South African Geographical Names Council (SAGNC) was established in 1998. Its vision is to promote reparation through symbolic measures with no restrictions on economic cost. Thus then Deputy President Jacob Zuma, referring to the national flag in a Heritage Day speech [in 2003] said, "One could argue that the design is not cost-effective, but our objectives were greater than the merely economic" (cited in Jenkins, 2003:8).

The SAGNC is currently dealing with the names of provinces, towns, cities, airports and natural features, while local names are the responsibility of municipal councils. The SAGNC is a consultative committee appointed by the national Minister of Arts and Culture. Only the Ministry can take the final decisions on name changes. SAGNC has to look at incorrectly spelt names, 'corrupted' names, and name changes of town and cities. In 2003, the SAGNC was decentralised to the provincial sphere. SAGNC is required to facilitate name changes but the proposals for the changes must emanate from the community, although these are sometimes influenced strongly by its leaders.

Now, according to the same law, or act, each province had to establish a Geographical Names Committee (GNC). So I'm a member of the Eastern Cape GNC. Our brief is to facilitate name change in the Province. Now it's very important to underline this point. We don't change names. We don't have the power to do that. We can only recommend name change to the SAGNC. The SAGNC refers the recommendations to the minister, and only the minister has the jurisdiction to authorise name changes. And what kind of names do we facilitate; do we have the power to recommend changing? ... all natural and human made features, such as the names of towns, rivers, mountains, parks, areas, districts. We have the authority to recommend the change of those names. But we cannot recommend the change of a street name. That is the responsibility of the local authority. We can also not change the names of cemeteries, or the local library of the town. Those names - only the local authority can decide on that. If someone wants to change a name, then one can apply for a name change. ${ }^{9}$

Emotional and perceptive aspects must be taken into consideration, and these could slow down the name change process. Individuals and communities currently advocating for changes in names argue in favour of eliminating traces or evidence of white oppression. They contend that the cost of these changes is nothing in comparison to the cost that blacks suffered under colonialism and apartheid. It is now time to restore African identity. On the other hand, opponents of name changes are mainly historically advantaged white residents who are resisting the loss of territoriality and the 'internal' postcolonial challenge to their (white/self) history (Jacobs, 2002). These residents argue that name changes must unify the people, not divide them. Given that there are other urgent development priorities in the country, they maintain that name changes constitute an unnecessary expenditure and will also impede marketing South Africa abroad. They stress that changing names is a 'political game' that pleases the egos of ANC politicians. ${ }^{10}$ In short, these residents seek to redirect the issue of the change of place names to an affirmation of their presence and history in the current context of black political domination and hegemony.

When names change, there should be a specified period within which they are rendered in the old and new versions in order that people become familiar with the new 
names (as, for example, the case of street names in Pietermaritzburg [Msunduzi Municipality] in 2006). This process might conflict with nation-building motives that would like to see all vestiges of a former dispensation removed as soon as possible (Ormeling, 1997). The inherent changes in the creation of place names should be an inclusive process of reconciliation, but they also hold the potential for social exclusion.

\section{The Making of a New Identity of Place}

This section of the paper focuses on the creation of place names linked to the new provincial and municipal demarcations in South Africa in the Year 2000. These new demarcations sought to address the inequalities stemming from territorial segregation and apartheid, and to build new integrative, redistributive and non-racial political territories (Guyot, 2006; Seethal, 2002, 2005). However, related questions remain, namely: Will the new territories be only political and administrative, or will they be a new place of reference for citizens' identities? How can the naming of these territories create links with citizens' daily lives and representations? In general, the names of towns, cities, suburbs and streets are closer to the people, but confusion also surrounds the names of municipalities and those of their main towns and cities. In consequence, it is anticipated that the names of some of these towns and cities will change too.

Changing the names of provinces is already a well-known subject (GervaisLambony, 1997; Guillorel, 2003). The names of the new provinces have tended to unify South Africans. For example, Gauteng means "place of gold" in Sesotho. The word derives from "gauta", gold, which comes from an Afrikaans word, 'goud'. Isinguni languages use a close word too, 'iRhauteni', with the same pronunciation. So, Gauteng is a well-considered choice, because everybody accepts it (Guillorel, 2003). KwaZulu-Natal is the only provincial name in South Africa composed of its former territorial components, the province, 'Natal', and homeland, 'KwaZulu'. Today there is still a debate on the name change for the Eastern Cape Province.

The process of municipality (re)naming was quick and not well regulated. In general, only a few residents were consulted. There are fewer municipalities today than before 2000, and most of their names reflect the mother languages of the newly elected black councillors. For example, in the Eastern Cape $79 \%$ of the municipalities now have Xhosa names against only $21 \%$ before (see Table 2 ). This reflects better the population demographics of the municipalities.

\section{Table 2}

Another principal feature of the majority of municipalities is that their names derive from one the nine official African languages, although provincial differences are interesting (Table 3). In Gauteng, there is resistance to 'white' names (33\% in total) while in the Western Cape, place names reflect the dominant language (Afrikaans) of the population there. On the other hand, in the Free State - the historical 'territorial symbol' for the Afrikaners - $96 \%$ of the municipalities are now named in one of the African languages.

\section{Table 3 and Table 4}


The categories of names chosen for new municipalities highlight significant characteristics (Table 4). KwaZulu-Natal and Free State are the provinces with the largest number of names related to culture (tradition, identity and customs). This is especially the case in KwaZulu-Natal where the Zulu culture is dominant. In the Western Cape and in the Mpumalanga, 30\% of the names are related to historically famous men (but not women), with use of the names of white men in the Western Cape (Oudtshoorn and Laingsburg), and 'resistance' heroes in the Mpumalanga (Albert Luthuli and Govan Mbeki). The names of 'resistance' heroes also feature prominently as municipal names in the Eastern Cape (e.g., Oliver Tambo District Municipality, Alfred Nzo District Municipality and Chris Hani District Municipality).

In total 46 municipalities are named after famous individuals: $40 \%$ of them after a white person, $30 \%$ after a black person from pre-colonial time and only $27 \%$ after an apartheid resistance hero (Table 4). In certain instances, the name changes have been striking. For example, one of the Eastern Cape Geographical Name Committee members advised that he was working at the Walter Sisulu University (formerly the University of Transkei), located in Nelson Mandela Drive in King Dalingwebo Sabata Local Municipality, within the Oliver Tambo District Municipality! This example illustrates that the change of place names in South Africa can be very symbolic in entrenching the current political order and in legitimating the new territorialisation process in terms acceptable to the majority population. In this legitimatising process, the concept of the 'African Renaissance' is important. Thus Nethersole (2002:144) writes, "The 'African Renaissance' rebirth is tilted towards the majority of black South Africans for the purpose of releasing traditional values and energies from a local history of colonization and oppression".

The African Renaissance can be understood as a consequence of globalisation with its pressure on reclaiming identity as a collective or communitarian initiative. The rebirth of an African identity is perceived to be the successor to the 1994 liberation, and precursor to the success of the coming 'African century' (Nethersole, 2002). In terms of Nethersole's perspectives, President Mbeki's concern with the African Renaissance lends itself to ambiguous interpretations, although officially it is an elaboration of inclusive non-racialism. In this regard Moodley and Adam (2000:55) note that, "Members of minority groups therefore frequently doubt whether they are genuinely included in the official political definition of an authentic African when popular perceptions emphasise cultural African traditions."

The heart of the South African dilemma resides in the tension between the ideal of colour blindness and the need to recognise race in order to diminish the reality of colour inequity (Moodley \& Adam, 2000). To achieve this aim, the African Renaissance legitimates new post-modern values supposedly coming from Africa's glorious precolonial history during which solidarity existed between different peoples. The new post-modern values, incorporated in the Republic of South Africa Constitution, are liberal and individual, with respect for the right to difference. While it may be argued that the old pre-colonial values were more conservative and respectful of social gradation, the African Renaissance tries to address these contradictions and simultaneously link South Africa with its historical past (Coombes, 2004). In essence, the African Renaissance is pan-Africanist in its geographical foundations and precolonial in its historical foundations. Thus, in October 2001, Themba Wakashe representing Dr. Ben Ngubane, then South Africa's Minister of Arts and Culture, at the 
official launch of the South African Geographical Names Committee for KwaZuluNatal in Durban said:

There is an urgent need to transform the national heritage landscape through renaming. South Africa's geographical features that were stripped of their original identities have to reclaim such identities. The process of rerenaming is an exciting and a challenging one and forms an integral part of the African Renaissance project. ${ }^{11}$

One of the ways in the renaming process is to use pre-colonial historical references. However, pre-colonial historical facts are sometimes difficult to establish and verify. In addition, there is also competition among the different official languages, including isiZulu, isiXhosa, Sesotho and Tswana. One solution is to refer to an even 'older' history, the one of the Khoi-San, the oldest known indigenous people of South Africa. There is even an obsession in South Africa to refer to the San culture, as Jenkins (2004) highlights with particular reference to the Coat of Arms. The choice of San figures as symbols in the new Coat of Arms can be explained as "an attempt by the Government to go back to a neutral 'pan-human' period, before successive waves of Khoi, black and white people arrived and persecuted the San" (Jenkins, 2003:18). The question of aboriginality is central here to legitimise the idea of nation. Sometimes the government will also use particular reference to famous African events or places outside South Africa in an attempt to pan-Africanise South Africa (Guillorel, 2003).

\section{Figure 1}

The example of Coega (Figure 1), the new port and industrial area near Port Elizabeth, is representative of these two African Renaissance motivations: the precolonial and pan-Africanism. Coega is a Khoikhoi name meaning, "underground water". Port-Elizabeth (Nelson Mandela Metropolitan Area) residents have not challenged this name because the first inhabitants of the area named this place. Also, the Government's port and industrial development project at Coega, Eastern Cape, refers to a strong symbol of the lighthouse in Alexandria, Egypt. (The name of the small town of Alexandria only $50 \mathrm{~km}$ away from Coega is only a coincidence!). However, the name of the Coega port is "Ngqura", a Xhosa word. These two names have not yet facilitated the marketing of the place, which is still waiting for international investors since Péchiney, the French aluminium smelter, has decided against investing in the area. ${ }^{12}$ Generally "internationally connected places" are likely to survive the African Renaissance with the use of English still dominant as the lingua franca. Similarly, the names of Cape Town, The Garden Road and Table Mountain are not likely to change because they are international and tourism symbols of South Africa. Furthermore, the black residents are in a minority in these areas and have not contested these names.

At the local level, the renaming process is not always smooth. East London is an interesting case of a very English place name being challenged today by another English place name, Buffalo City. Coetser (2005) explains the history of the Anglicisation process at East London and how most of the communities were not properly represented, and felt apart. Segregation started there with naming. Thus Coetser contends: 
In 1835 the first English landed here at the mouth of the Buffalo River. 'Let's call it East London': London in Britain in the East. In other words they tried to transplant the concept, the identity, the political sphere, the social sphere, all those values they tried to transplant here, and they called it East London. The Xhosa People, called this 'iMonti'. 'Mont' comes from the Afrikaans word for Mont, being mouth - the mouth of the Buffalo River. ... The English colonists as they came in ... started expanding, and all the surrounding suburbs ... had English names. ${ }^{13}$

The new name for the greater East London area, namely 'Buffalo City Municipality', is confusing at an international level. It does not resolve African identity frustrations and it create conflicts amongst the white population who regard it as costly, and without benefits. ${ }^{14}$ Moreover, another Buffalo City already exists on the shores of Lake Erie in the United States. Elected white councillors (in opposition to the African National Congress [ANC]) and white residents regard the name change as a waste of time and money, and a challenge to their history. They argue that, "One can change a name but one does not rewrite the history," and "Buffalo City is less of an evil and much better than an unpronounceable Xhosa name". ${ }^{15}$ These views of the white residents and opposition councillors are different from those of the black ANC municipal councillor in charge of the renaming committee. He contends that, "there is a great legitimacy to erase Afrikaner names because Afrikaners do not have a country. They came to steal South Africa". ${ }^{16}$ On the other hand, he does not question the retention of English names "because everyone understands English. Moreover the United Kingdom is a country, which seems to give to these place names a real legitimacy".

Many residents do not refer to Buffalo City Municipality as a new territory of identity. Rather, they refer to the name of the place where they were born or the suburb where they live, or just to East London. For them, Buffalo City as a territory will soon be synonymous with 'rates and taxes', even though the payment for services is difficult given that unemployment is high. Clearly, the level of identification for citizens is at a lower scale: house, street and shopping mall names. For example, while the views of the residents are recognised, the name of the town or the city plays an important identification role at a regional and national level.

\section{Places of Multi-Identities?}

This section examines the ambiguity in the identities of places between the new municipalities and their main cities or towns. What is the territorial reference in terms of urban identity (urbanity) for South African citizens, the new municipality as a whole, the former apartheid town, and the city centre? In essence, this depends on the person: whether you are a politician, a businessman, a citizen or a tourist. This is why this issue is complex and very sensitive in South Africa. Territorial levels of spatial identities are different for different people. Perhaps, the name should reflect the will of the majority. The central issue around the renaming of Pretoria (Figure 2), as indicated on the first page of the Tshwane Municipality web site is representative of this: 
Tshwane, the administrative capital and the birthplace of the new South African democracy, is home to a large diplomatic community. Well over a hundred embassies and foreign missions are located here, making Tshwane the ideal base for international trade and for liaison with political decisionmakers from all over the world. ${ }^{17}$

\section{Figure 2}

Tshwane means that, "we are (the same) together". It is derived from a Mushi chief who came to the area 100 years before the arrival of the whites. Blacks want to show that they were there first - hence the metropolitan city municipality is named after him. The city centre will stay Pretoria. The question that remains though is what territorial level will be used at the international level: the metropolitan area or the city centre? This constitutes the main worry of the opponents of the name, 'Tshwane'. From a symbolic point of view the cartoonist, Zapiro, correctly illustrates that some people will lose the power of territorial identification in the process (Figure 3).

\section{Figure 3}

In comparison, however, the case of KwaZulu-Natal's primate city-area is different from that for Tshwane and Pretoria. In this instance, the Metropolitan Municipality is eThekwini, the name the Zulus used when referring to Durban. This place name is already rooted locally and was only awaiting its official proclamation. In short, a given place can generate a particular identity, and a place can be named after its identity.

\section{Conclusion}

South Africa is struggling with the competing demands of difference and unity as it seeks to reconstruct itself in a more humane and equitable way in the postapartheid era. Far from disappearing, arguments about national belonging and racial and ethnic differences have become increasingly prominent in South Africa in the 1990s. The change or creation of place names can be seen as a way to unify the identity of citizens with different languages and cultures. At the same time, changes in place names can serve as a tool to divide society. The name-changing process is essentially geared towards achieving two aims: nation building - both geographically and historically, and politico-territorial 'marketing'. The process of changing or creating place names suggests that South Africa is on its way to achieving a peaceful, culturally differentiated communitarianism after a prolonged period of white colonial domination and apartheid. The South African case study also shows that whites will defend a place name to preserve its identity, roots and symbols. While this, in one sense, corresponds to the idea of a rainbow nation, the study records the tendency towards an African homogenisation of place names that seeks increasingly to legitimise the new political regime by honouring contemporary and recently deceased liberation heroes. White residents perceive this process of homogenisation as a symbolic of the new hegemony, and contrary to the creation of a true South African identity.

The process of changing and creating place names also illustrates the nature of the historical project for the new South Africa. Two earlier disputed historical periods are involved, namely, the colonization and the apartheid era. The political strategy to 
set up a new history is marked by the use of older pre-colonial references, sometimes more neutral (like with the Khoisans), external to the country, or borrowed from nature - a strategy that Horsman (2006) identified for the former Soviet Union in the post Soviet period. Even if the problems and tensions are varied and numerous, compromises will be found between and among the different communities. These compromises have already been made through informal and imaginative place naming. The more modest goal of political education therefore should be one that recognises the role of different identities, as well as the moral significance of conflicting claims. Democratic ways of conflict resolution should be fostered rather than the idealistic clamouring for unifying national values. Promoting tolerance of, and respect for, political opponents contributes more to democratic nation building than the utopian common memory or an official history about a divisive past. Even if some names disappear they will still be part of the imaginary South African history and will help younger generations to keep an eye on the past. 


\section{REFERENCES}

Bekker S. and Prinsloo R. (eds.). 1999. Identity? Theory, Politics, History. Pretoria, HSRC Press.

Bopda A., 2001. De l'usage de fonds mythiques dans les remaniements territoriaux en Afrique et au Cameroun. Cahiers de géographie du Québec, 45, 126, 451-478.

Brown D. 2001. National belonging and cultural difference: South Africa and the global imaginary. Journal of Southern African Studies, 27(4), 757-769.

Coetser A. Echelons of power and naming practices: a case study, Nomina Africana, 18, $1 \& 2$, in press.

Coetser A. 2002. How far back with name changes? Conference paper presented at the $12^{\text {th }}$ International Conference of the Names Society of Southern Africa, Bloemfontein. $17-21$ July 2002

Coombes. A.E. 2004. Visual culture and public memory in a democratic South Africa. Johannesburg, Wits University Press.

de Jager, N. 2005. South Africa: an emerging national identity. Centre for International Political Studies (CIPS). Electronic Briefing Paper, www.up.ac.za/academic/cips. (Accessed: 04 January 2006).

Dixon J. and Durrheim K. 2000. Displacing place-identity: A discursive approach to locating self and other. British Journal of Social Psychology, 39, 27-44.

Flowerdew, R. and Martin, D. (eds.). 2005. Methods in human geography. (2 $2^{\text {nd }}$ ed.). Pearson, Harlow.

Gervais-Lambony P. 1997. L'Afrique du Sud et les Etats voisins . Paris, Armand Colin, collection"U".

Guillorel H. 2003. Toponymie et politique : l'exemple de l'Afrique du Sud. Conference paper presented at the $19^{\text {th }}$ international conference of AFSP, Durban.

Guyot S. 2006. Rivages Zoulous : l'environnement au service du politique. Paris: Karthala/IRD.

Guyot S., Gebrati F., Seethal C., Giraut F., Antheaume B. 2005. The question of the change of place names in post-apartheid South Africa. Conference paper presented at the SSAG Conference, Cape Town, 7 -9 September 2005.

Hoggart, K., Lees, L. and Davies, A. 2002. Researching human geography. Arnold, London. 
Horsman, S. 2006. The politics of toponyms in the Pamir mountains. Area, 38(3), 279291.

Jacobs, J.M. 2002. (Post)Colonial spaces. In M. Dear \& S. Flusty (Eds.) The spaces of postmodernity - Readings in human geography (pp. 192-199). Blackwell: Maiden, Massachusetts, USA.

Jenkins, E. 1990. From Leliefontein to Megawatt Park: some trends in the naming of South African places. English Academy Review, 7, 60-67.

Jenkins, E. 2004. Symbols of nationhood. Presidential address, South African Institute of Race Relations. Braamfontein, Johannesburg. 32 p.

Limb, M. and Dwyer, C. (eds.). 2001. Qualitative methods for geographers - Issues and debates. Arnold, London.

Low S.M. and Lawrence-Zuniga D. (eds.). 2003. The anthropology of space and place: locating culture. London, Blackwell Publishers.

Mamdani, M. 1996, Citizen and Subject. Contemporary Africa and the Legacy of Late Colonialism. Princeton, Princeton University Press.

Meiring B. 1994. Toponymic innovation and social change. Nomina Africana, 8(1), 6579.

Moodley K. and Adam, H. 2000. Race and nation in post-apartheid South Africa. Current Sociology, 48(3), 51-69.

Nethersole R. 2002. Reclaiming identity as truth: on the politics of the African Renaissance. Quest: An African Journal of Philosophy, 16(1-2), 143-150.

Ormeling F. 1997. Cartographic problems in a multilingual society: mapping the new South Africa's place names. Nomina Africana, 11(1), 37-50.

Palmberg M. (ed.). 1999. National Identity and Democracy in Africa. Pretoria, HSRC Press.

Ranger T. 1989. Whose heritage? The case of the Matobo National Park. Journal of South African Studies, 15, 217-249.

Ranger T. 1996. Great spaces washed with sun: the Matopos and Uluru [Ayer's Rock] compared, in Kate Darian-Smith, Liz Gunner and Sarah Nuttall (eds), Text, Theory, Space: Land, Literature and History in South Africa and Australia, London, Routledge.

Raper P.E. 1989. A dictionary of Southern African Place Names. Second edition, Johannesburg: Jonathan Ball Publishers. 
Reid B. 2004. Labouring towards the space to belong: place and identity in Northern Ireland. Irish Geography, 37(1), 103-113.

Ryan L. 2005. Identity, conflict, and memory in Cape Town's public spaces: unearthing the Waterfront. Postamble, 1(2), 34-43.

Seethal, C. 2002. Regenerating rural economies: The case of Limehill, South Africa. GeoJournal, 57(1-2), 61-73.

Seethal, C. 2005. Postmodern urban politics in South Africa: The case of Stellenbosch (2000-2004). South African Geographical Journal, 87(2). 141-151.

Snyman G. 2005. Constructing and deconstructing identities in post-apartheid South Africa: a case of hybridity versus untainted Africanicity? Conference paper presented at the Rhetoric of Identity Conference, Redlands, CA, January 2005. 
Table 1. Types of Place Names in South Africa

\begin{tabular}{|l|l|l|}
\hline $\begin{array}{l}\text { Place name } \\
\text { level }\end{array}$ & $\begin{array}{l}\text { Name making } \\
\text { decision level }\end{array}$ & $\begin{array}{l}\text { International } \\
\text { marketing } \\
\text { power }\end{array}$ \\
\hline Country & National & Very strong \\
\hline Province & National/ provincial & Strong \\
\hline District & Local & Variable \\
\hline Municipality & Local & Variable \\
\hline Town / City & $\begin{array}{l}\text { National/provincial/ } \\
\text { local }\end{array}$ & Strong \\
\hline Formal suburb & $\begin{array}{l}\text { Local (before } \\
\text { national) }\end{array}$ & Weak \\
\hline $\begin{array}{l}\text { Informal } \\
\text { settlement }\end{array}$ & Micro-local & Very weak \\
\hline $\begin{array}{l}\text { Buildings, } \\
\text { monuments }\end{array}$ & $\begin{array}{l}\text { National/provincial/ } \\
\text { local }\end{array}$ & Variable \\
\hline Streets & Local & Weak \\
\hline $\begin{array}{l}\text { Natural } \\
\text { features }\end{array}$ & National & Variable \\
\hline
\end{tabular}

Table 2. Evolution of Names of Municipalities in the Eastern Cape

\begin{tabular}{|l|l|l|}
\hline Language & Pre-1995 & Post-2000 \\
\hline Xhosa & $21 \%$ & $\mathbf{7 9 \%}$ \\
\hline English & $\mathbf{4 8 \%}$ & $13 \%$ \\
\hline Afrikaans & $31 \%$ & $8 \%$ \\
\hline $\begin{array}{l}\text { Total number of } \\
\text { municipalities }\end{array}$ & $104(100 \%)$ & $39(100 \%)$ \\
\hline
\end{tabular}

Source: www.sagnc.org.za 
Table 3. Languages of New Municipal Names, South Africa

\begin{tabular}{|l|l|l|l|}
\cline { 2 - 4 } \multicolumn{1}{c|}{} & \multicolumn{3}{c|}{\begin{tabular}{c} 
Percent Municipal Names \\
\multicolumn{1}{c|}{}
\end{tabular}} \\
\begin{tabular}{|l} 
Jurisdictional \\
Area
\end{tabular} & $\begin{array}{l}\text { One of the } \\
\text { African } \\
\text { languages }\end{array}$ & English & Afrikaans \\
\hline $\begin{array}{l}\text { South Africa } \\
\text { (total) }\end{array}$ & $\mathbf{7 4 , 6}$ & $\mathbf{1 1 , 7}$ Language \\
\hline Gauteng & 66,7 & 20 & $\mathbf{1 3 , 7}$ \\
\hline KwaZulu-Natal & 87,9 & 8,4 & 13,3 \\
\hline Western Cape & 16,7 & 36,7 & 3,7 \\
\hline Free State & 96 & 4 & 46,6 \\
\hline Eastern Cape & 82,8 & 10,9 & 0 \\
\hline Northern Cape & 74,2 & 0 & 6,3 \\
\hline Limpopo & 81,2 & 9,4 & 25,8 \\
\hline North West & 68 & 8 & 9,4 \\
\hline Mpumalanga & 80 & 15 & 24 \\
\hline
\end{tabular}

Source: www.sagnc.org.za

Table 4. Categories of New Municipal Names (South Africa)

\begin{tabular}{|c|c|c|c|c|}
\hline \multirow[b]{2}{*}{$\begin{array}{c}\text { Jurisdictional } \\
\text { Area }\end{array}$} & \multicolumn{4}{|c|}{$\begin{array}{l}\text { Category of Municipal Name, } \\
\text { by number and percent }\end{array}$} \\
\hline & $\begin{array}{l}\text { Geographical } \\
\text { (nature and } \\
\text { space) }\end{array}$ & $\begin{array}{l}\text { Cultural } \\
\text { (tradition, } \\
\text { identity, } \\
\text { customs...) }\end{array}$ & $\begin{array}{l}\text { Famous man (or } \\
\text { woman) }\end{array}$ & Total \\
\hline $\begin{array}{l}\text { South Africa } \\
\text { (total) }\end{array}$ & $157(55,5 \%)$ & $80(28,3 \%)$ & $46(16,2 \%)$ & $\begin{array}{l}283 \\
(100 \%)\end{array}$ \\
\hline Gauteng & $10(66,7)$ & $2(13,3)$ & $3(20)$ & $15(100)$ \\
\hline KwaZulu-Natal & $27(45,8)$ & $27(45,8)$ & $5(8,4)$ & 59 \\
\hline Western Cape & $19(63,3)$ & $2(6,7)$ & $9(\mathbf{3 0})$ & 30 \\
\hline Free State & $11(44)$ & $12(48)$ & $2(8)$ & 25 \\
\hline Eastern Cape & $28(61)$ & $9(19,5)$ & $9(19,5)$ & 46 \\
\hline Northern Cape & $17(55)$ & $10(32)$ & $4(13)$ & 31 \\
\hline Limpopo & $18(56,3)$ & $10(31,2)$ & $4(12,5)$ & 32 \\
\hline North West & $15(60)$ & $6(24)$ & $4(16)$ & 25 \\
\hline Mpumalanga & $12(60)$ & $2(10)$ & $6(\mathbf{3 0})$ & 20 \\
\hline
\end{tabular}

Source. www.sagnc.org.za 


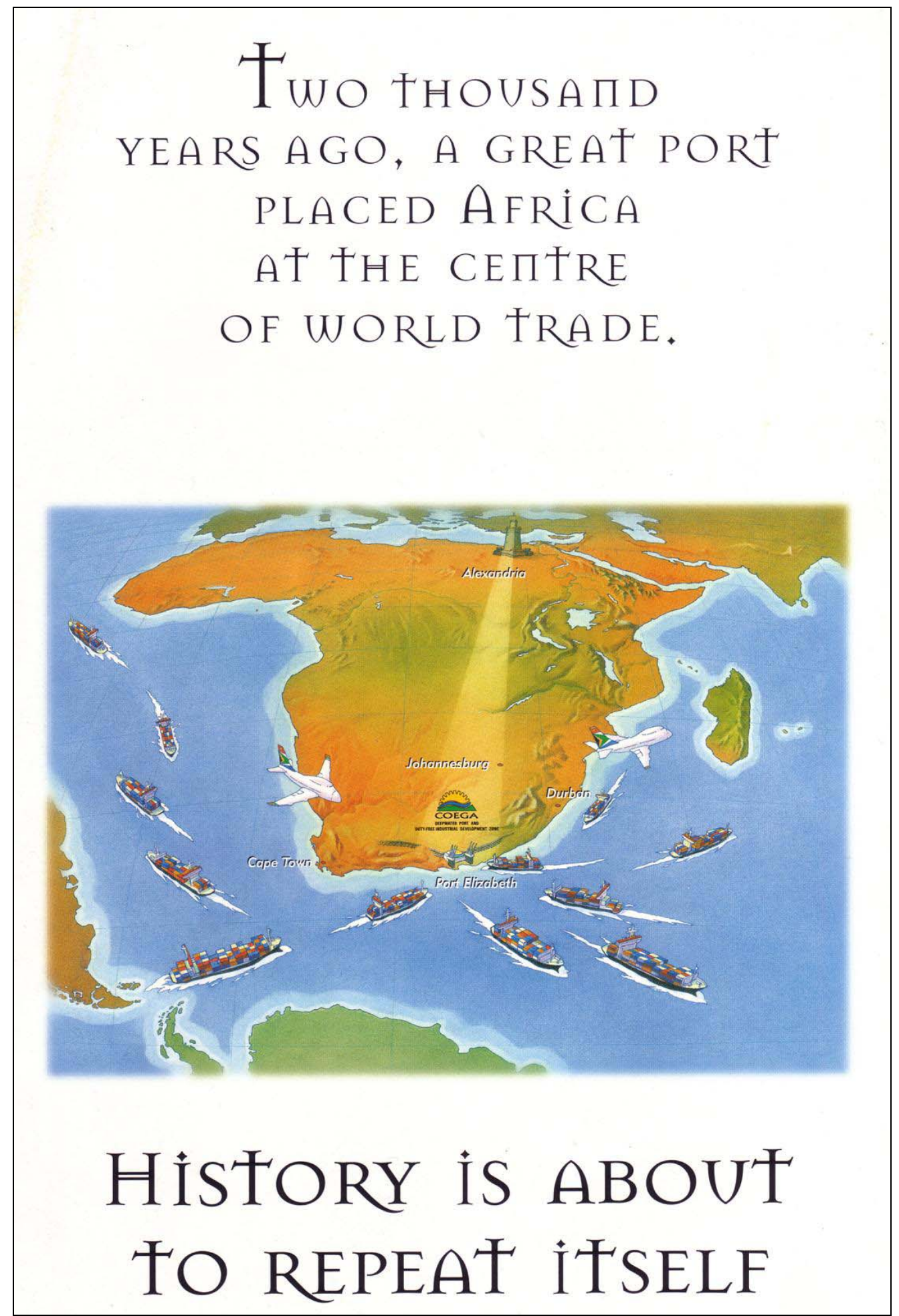

Figure 1. Coega (South Africa) and Alexandria (Egypt) - Towards a glorious pan-African, pre-colonial history 


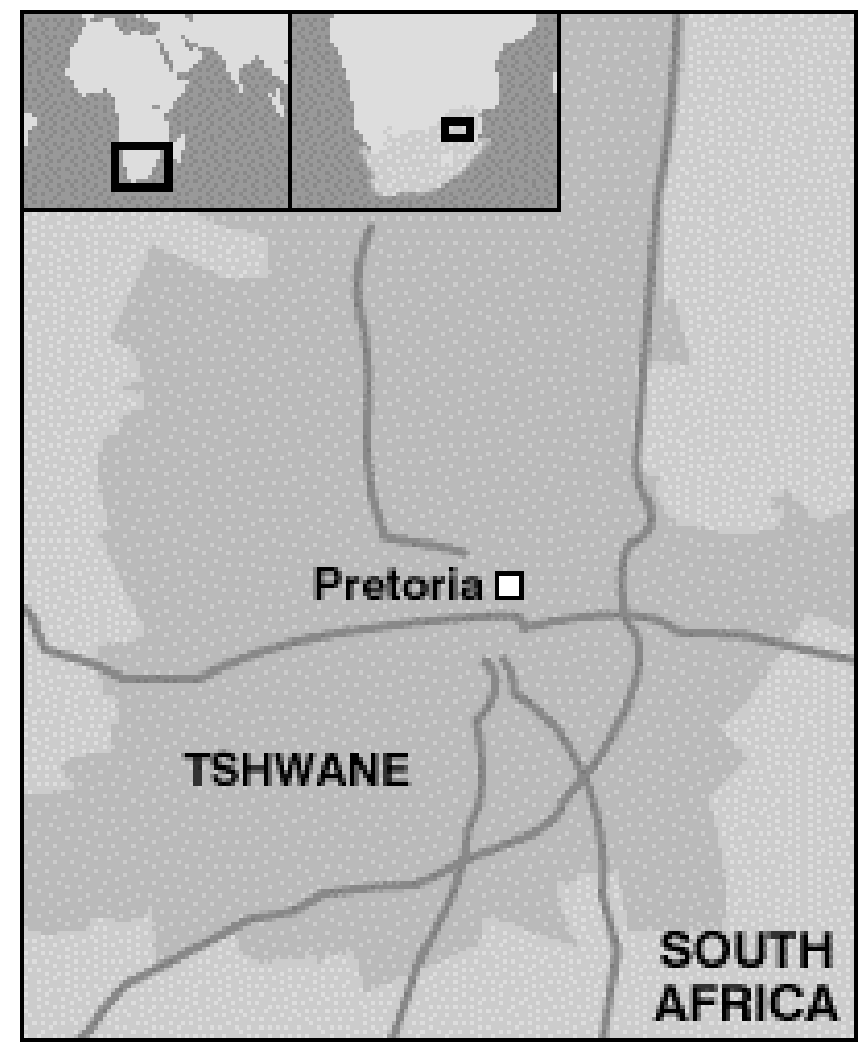

Figure 2. City of Pretoria and Metropolitan Tshwane (Source: www.tshwane.org.za;

Accessed 01 September, 2005) 


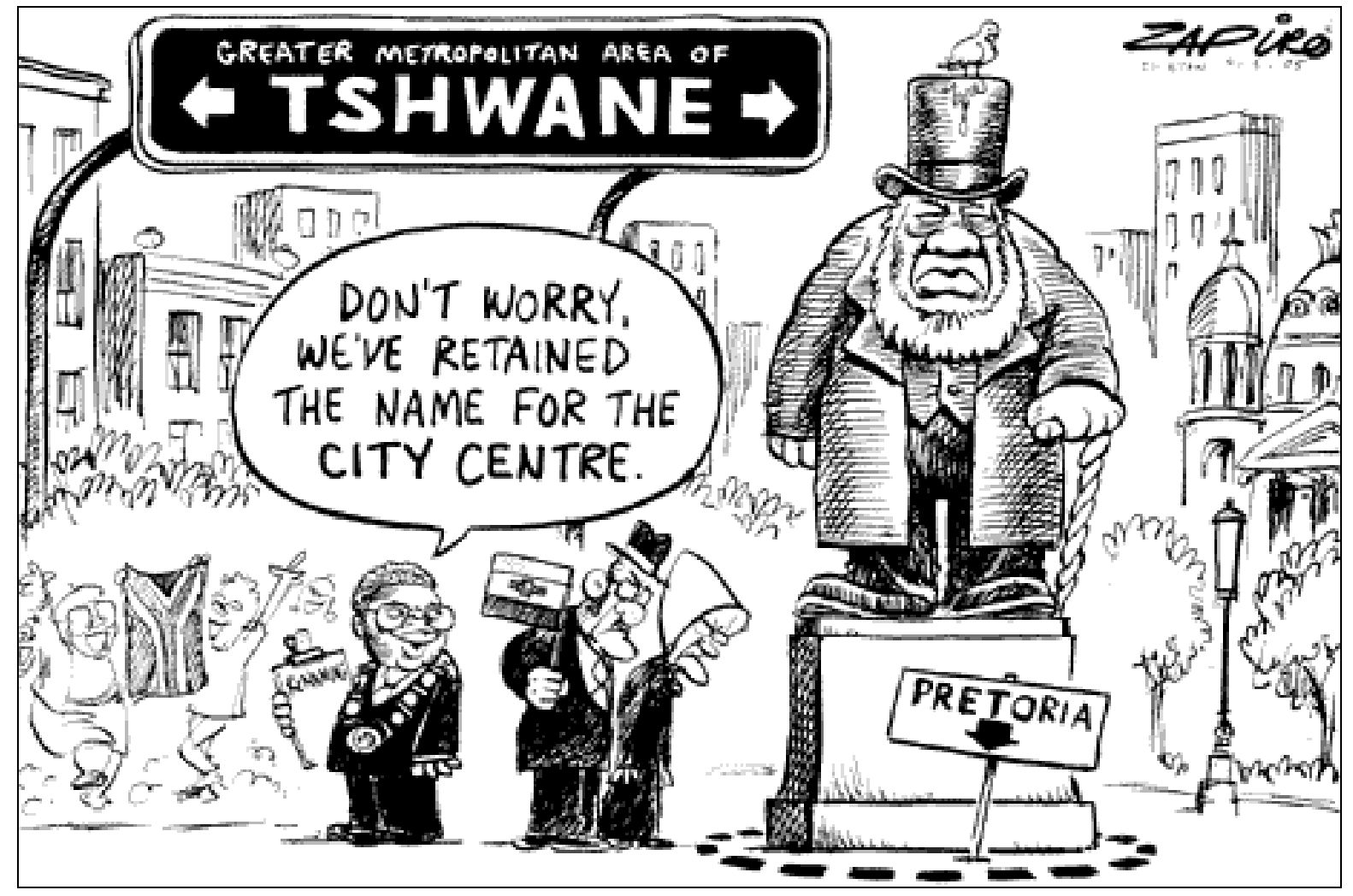

Figure 3. Identity and Territoriality - Pretoria and Metropolitan Tshwane (Source: Cartoonist 'Zapiro', Mail \&Guardian, March 2005) 


\section{$\underline{\text { Endnotes }}$}

${ }^{1}$ Source: http://africanlanguages.com/south_africa/place_names.html, accessed $1^{\text {st }}$ September 2005. This web site is dedicated to the study of African languages.

${ }^{2}$ Source: $\mathrm{http}: / /$ www.mltranslations.org/SouthAfrica/Sapamphl.htm\#Pan-

Africanist $\% 20$ Congress $\% 20$ Congress $\% 20$ (PAC, accessed 02 October 2006;

http://dictionary.laborlawtalk.com/SouthAfrica, accessed 02 October 2006.

${ }^{3}$ Source: Napier, C. "Symbols and symbolism," in http://www.unisa.ac.za.defaut.asp, accessed 02

October 2006.

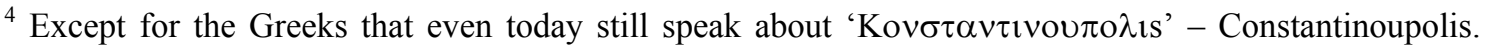
Greeks refer to Istanbul as Constantinople not simply out of residual nationalist feelings, but because the ancient form of 'Constantinople', not Istanbul, remains the title of the most important patriarch of the Greek Orthodox Church.

${ }_{6}^{5}$ Personal communication, Eastern Cape Geographical Names Committee Member, $10^{\text {th }}$ November, 2004.

${ }^{6}$ Amongst the individuals interviewed were Professors E. Jenkins and A. Coetser.

${ }^{7}$ This last aspect is not considered in detail, as it constitutes the subject matter of another paper.

${ }^{8}$ Personal communication, A. Coetser, $5^{\text {th }}$ November, 2004. Gonubie is a residential suburb in East London in the Buffalo City Municipality.

${ }^{9}$ Personal communication, Eastern Cape Geographical Names Committee member, $5^{\text {th }}$ November, 2004.

${ }^{10}$ Personal communications, Various individuals, East-London, November 2004.

${ }^{11}$ Address by the Deputy Director-General of the Department of Arts, Culture, Science and Technology, 12/10/2001, www.anc.org.za

${ }^{12}$ Personal communication, Péchiney management, $2^{\text {nd }}$ November, 2004.

${ }^{13}$ Personal communication, A. Coetser, $5^{\text {th }}$ November, 2004.

${ }^{14}$ Personal communication, East-London residents and councillors, 5-10 November, 2004.

${ }^{15}$ Personal communication, East-London residents and councillors, 5-10 November, 2004.

${ }^{16}$ Personal communication, East-London councillor, $10^{\text {th }}$ November, 2004.

${ }^{17}$ http://www.tshwane.gov.za/ accessed $1^{\text {st }}$ September 2005. 